ORIGINAL ARTICLE

\title{
Risk factors for work related violence in a health care organization
}

\author{
M J Findorff, P M McGovern, M Wall, S G Gerberich, B Alexander
}

Injury Prevention 2004;10:296-302. doi: 10.1136/ip.2003.004747

See end of article for authors' affiliations

....................

Correspondence to: Dr Mary Findorff,

University of Minnesota,

School of Public Health,

Mayo Mail Code 807, 420

Delaware St SE

Minneapolis, MN 55455

USA; find0003@umn.edu
Objective: Identify the exposure effects of job family, patient contact, and supervisor support on physical and non-physical work related violence.

Design: Cross sectional study of employees in a Midwest health care organization, utilizing a specially designed mailed questionnaire and employer secondary data.

Subjects: Respondents included 1751 current and former employees (42\% response rate).

Results: Physical and non-physical violence was experienced by $127(7.2 \%)$ and $536(30.6 \%)$ of the respondents, respectively. Multivariate analyses of physical violence identified increased odds for patient care assistants (odds ratio (OR) 2.5, 95\% confidence interval (CI) 1.1 to 6.1 ) and decreased odds for clerical workers (OR $0.1,95 \% \mathrm{Cl} 0.03$ to 0.5). Adjusted for job family, increased odds of physical violence were identified for moderate (OR 5.9, 95\% $\mathrm{Cl} 2.1$ to 16.0 ) and high (OR 7.8, 95\% $\mathrm{Cl} 2.9$ to 20.8) patient contact. Similar trends were identified for non-physical violence (OR $1.4,95 \% \mathrm{Cl} 1.1$ to 2.0 and OR 1.7 , $95 \% \mathrm{Cl} 1.3$ to 2.3 ). Increased supervisor support decreased the odds of both physical (OR $0.7,95 \% \mathrm{Cl} 0.6$ to 0.95 ) and non-physical violence (OR $0.5,95 \% \mathrm{Cl} 0.4$ to 0.6 ), adjusting for job family and demographic characteristics.

Conclusions: Increased odds of physical violence were identified for the job family of nurses, even when adjusted for patient contact. Increased patient contact resulted in increased physical and non-physical violence, independent of job family, while supervisor support resulted in decreased odds of physical and non-physical violence.
$\mathrm{V}$ iolence is the third most common cause of occupational death in the United States and the second leading cause for working women, accounting for 639 work related homicides in 2001, ${ }^{1}$ and nearly two million acts of non-fatal work related violence annually. ${ }^{2}$ Health care workers are at increased risk of non-fatal work related violence. ${ }^{3-5}$ Most studies addressing health care workers have focused on one occupation, nursing. ${ }^{6}{ }^{7}$ Injury rates per 100000 persons per year, based on workers' compensation claims for selected health care occupations, included registered nurses (27), licensed practical nurses (88), medical managers (116), occupational therapists (222), nursing aides (289), and health aides (457), compared with an overall rate of $16 .^{7}$ The vast majority of physical violence in health care is perpetrated by patients or clients. ${ }^{4-13}$

Risk factor identification for non-physical violence in health care workers has been limited because most studies have focused on lifetime prevalence of verbal abuse ${ }^{14-16}$ or sexual harassment by occupation without multivariate estimation of risk factors. ${ }^{117-24}$ One exception was a Minnesota nurses' study that estimated the annual incidence rate of non-physical violence, including threat, sexual harassment, and verbal abuse. ${ }^{12}$

The social climate and supportiveness in the workplace are important determinants of recovery from work related assaults, ${ }^{25-27}$ but there is minimal research into its role in preventing violence. Results from the Assaulted Staff Action Program demonstrated that offering support to victims, after an assault, has an effect on reducing future violence, though the mechanisms are unclear. ${ }^{28} 29$

Limitations in the research on risk factors of violence in health care employees are that most studies have been descriptive and focused solely on one occupation. While incident rates have been computed, multivariate analyses that control for important confounding factors have rarely been done. This study addresses those limitations by using an analytic approach to compare several occupational groups while adjusting for employment and demographic characteristics in a multivariate analysis, including patient contact and supervisor support.

\section{METHODS}

This was a cross sectional study of employees of a major Midwest health care organization. Institutional Review Boards for the University of Minnesota and the health care organization approved the survey instrument and study protocol prior to implementation.

\section{Hypotheses}

The hypotheses for physical and non-physical violence were that increased violence is associated with job family, where clinical personnel or those occupations having greater patient contact have a greater risk than non-clinical person-

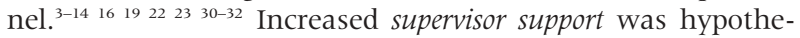
sized to be protective for both physical and non-physical violence. $^{28} 2933-36$

\section{Study population}

This study included current employees of a major Midwest health care system, as of May 2001, as well as individuals who left the organization within the previous 12 months. Selection criteria included a minimal employment of 12 weeks and 200 hours (0.1 full time equivalent (FTE)). The organization employed more than 21000 workers in hospitals, medical clinics, and administrative environments. Employees held a variety of jobs ranging from clinical positions (for example, nurses, patient care assistants, and

Abbreviations: $\mathrm{Cl}$, confidence interval; $\mathrm{FTE}$, full time equivalent; $\mathrm{OR}$, odds ratio; OSHA, Occupational Safety and Health Administration 
physicians) to clerical and technical positions (for example, accountants, computer programmers, and technicians).

\section{Sampling method}

The health system maintains an employee database that groups employees into job families. These job families contain similar occupations categorized for administrative purposes. In this study, job families were combined to include groupings that had a similar expected risk for physical violence; 14 separate categories resulted from which sampling was done. Proportionate random sampling based on the number of employees in each category was conducted to obtain valid estimates of the expected incidence of violence within each stratum, with 95\% confidence intervals.

\section{Data sources}

The primary source of data was the survey instrument. Employees randomly selected for the study were mailed a specifically designed and pre-tested survey instrument that addressed the incidence of violence, patient contact, and support measures, as well as demographic data.

The health system employee database was used to obtain information on employment characteristics (for example, job family, department, business unit or work setting, date of hire, date of termination, if applicable, and the number of hours the employee worked). Demographic data were obtained from this database (for example, date of birth, gender, wages or income, and race).

\section{Contact procedures and data collection}

Subjects received a notification letter, the survey instrument and a cover letter, consent form (reviewing the study goals and issues of confidentiality), and a stamped, return envelope addressed to the investigators. Follow up occurred for nonrespondents with postcard reminders, a second mailing of the survey, and a final one page survey sent to non-respondents.

\section{Definition of violence}

The health system's policy concerning violence stated: "Violence is broadly defined as words and actions that hurt people". Violent events that occurred between 1 April 2000 and 31 March 2001 were included in the study.

\section{Measures}

Physical violent events were measured by asking, "Were you the target of any work related physical assaults or other unacceptable physical contact (for example, shoving, hitting, kicking, biting, slapping, etc)?"

Non-physical violent events were measured by asking four questions taken directly from the organization's written policy and addressed the following: (1) words, stories, or comments that were found offensive; (2) written or graphic material that made the person feel angry or hostile; (3) other behavior felt to be threatening, intimidating, hostile, or offensive; and (4) unwelcome sexual advances being made a condition of employment. Examples were provided for each of the above questions.

Business unit, department, and job family were obtained from the employee database. The business units were comprised of two urban hospitals, two suburban hospitals, six regional hospitals, medical clinics, and other settings such as patient services and administrative locations. Departments consisted of individual work areas within the business units (for example, emergency, mental health, medical-surgical, and administrative). The 14 job families were further combined into seven categories for analysis based on hypothesized risk for physical violence identified from the literature and the expertise of the investigators.
Table 1 Demographic characteristics of sampled participants (weighted); values are number (\%) unless otherwise stated

\begin{tabular}{|c|c|c|}
\hline Characteristics & $\begin{array}{l}\text { Sampled } \\
(n=4166) \dagger\end{array}$ & $\begin{array}{l}\text { Respondents } \\
(\mathrm{n}=1751) \dagger\end{array}$ \\
\hline \multicolumn{3}{|l|}{ Gender } \\
\hline Female & $3352(80.5)$ & $1447(82.6)$ \\
\hline Male & $814(19.5)$ & 304 (17.4) \\
\hline \multicolumn{3}{|l|}{ Education } \\
\hline High school or less & * & $192(11.0)$ \\
\hline Some college & * & $841(48.0)$ \\
\hline College graduate & * & $482(27.5)$ \\
\hline Postgraduate & * & 231 (13.2) \\
\hline Missing & * & $5(0.3)$ \\
\hline \multicolumn{3}{|l|}{ Marital status } \\
\hline Married & * & $1114(63.6)$ \\
\hline Never married & * & $344(19.6)$ \\
\hline Separated, divorced, & * & $275(15.7)$ \\
\hline $\begin{array}{l}\text { or widowed } \\
\text { Missing }\end{array}$ & * & $18(1.0)$ \\
\hline \multicolumn{3}{|l|}{ Race } \\
\hline White & $3682(88.4)$ & 1625 (92.8) \\
\hline Non-white & $379(9.1)$ & $88(5.0)$ \\
\hline Not indicated & 105 (2.5) & $38(2.2)$ \\
\hline Mean (SD) age in years & $41.4(11.5)$ & $43.5(11.5)$ \\
\hline $\begin{array}{l}\text { Personal hourly income } \\
\text { (median) }\end{array}$ & $\$ 16.70$ & $\$ 17.64$ \\
\hline $\begin{array}{l}\text { Personal annual income } \\
\text { (median) }\end{array}$ & $\$ 27781$ & $\$ 29476$ \\
\hline \multicolumn{3}{|l|}{ Family income } \\
\hline$<\$ 20000$ & * & $71(4.1)$ \\
\hline$\$ 20000-39999$ & * & $354(20.2)$ \\
\hline$\$ 40000-59999$ & * & $443(25.3)$ \\
\hline$\$ 60000-79999$ & * & $316(18.0)$ \\
\hline$\$ 80000-99999$ & * & $220(12.5)$ \\
\hline$\$ 100000+$ & * & $247(14.1)$ \\
\hline Missing & * & $100(5.7)$ \\
\hline \multicolumn{3}{|l|}{ Hours worked per week } \\
\hline $40+$ & $1896(45.5)$ & $870(49.7)$ \\
\hline $20-39$ & $1700(40.8)$ & $781(44.6)$ \\
\hline$<20$ & $212(5.1)$ & $100(5.7)$ \\
\hline Missing & $358(8.6)$ & 0 \\
\hline
\end{tabular}

Patient contact was a proportion computed from the individual's average number of patient contact hours at work per week, including face-to-face contact and telephone interaction with patients, divided by the average number of hours worked per week.

Supervisor support was measured by two questions from Karasek's Job Content Questionnaire ${ }^{37}$ : "My supervisor was concerned about the welfare of those under him or her" and "I was exposed to hostility or conflict from my supervisor". The dates for all support questions were before those used for assessment of violence to obtain a baseline of information prior to the violent events.

\section{Data analysis}

The goal of this study was to measure the effect of job family, patient contact, and supervisor support on the incidence of physical and non-physical violence, controlling for confounding factors. A conceptual model was created, incorporating exposures of interest from the literature, to determine which variables to include in the analysis.

Summary statistics were used to describe the associations between the dependent variables (incidence of physical violence; incidence of non-physical violence) and the independent variables (job family, business unit, department, patient contact, supervisor support, age, gender, education, and income). The two dependent variables were dichotomized, with one group representing those who experienced work related violence in the past 12 months and the other 
Table 2 Demographic characteristics of respondents with respect to experience with violence (weighted); values are number (\%) unless otherwise stated

\begin{tabular}{|c|c|c|c|}
\hline Characteristics & $\begin{array}{l}\text { Physical violence } \\
(\mathrm{n}=127)^{*} \dagger\end{array}$ & $\begin{array}{l}\text { Non-physical violence } \\
(\mathrm{n}=536) \dagger\end{array}$ & $\begin{array}{l}\text { Neither physical nor non- } \\
\text { physical violence } \\
\text { ( } n=1148) \dagger\end{array}$ \\
\hline \multicolumn{4}{|l|}{ Gender } \\
\hline Female & $104(82.5)$ & $455(84.9)$ & $933(81.3)$ \\
\hline Male & $22(17.5)$ & $81(15.1)$ & $215(18.7)$ \\
\hline \multicolumn{4}{|l|}{ Education } \\
\hline High school or less & $3(2.2)$ & $51(9.5)$ & $139(12.1)$ \\
\hline Some college & $61(48.2)$ & $248(46.3)$ & $559(48.7)$ \\
\hline College graduate & $50(39.3)$ & $174(32.4)$ & $282(24.5)$ \\
\hline Postgraduate & $13(10.4)$ & $62(11.6)$ & $166(14.5)$ \\
\hline Missing & 0 & $1(0.3)$ & $2(0.2)$ \\
\hline \multicolumn{4}{|l|}{ Marital status } \\
\hline Married & $79(62.8)$ & $337(62.9)$ & $729(63.5)$ \\
\hline Never married & $26(20.5)$ & $117(21.9)$ & $217(18.9)$ \\
\hline $\begin{array}{l}\text { Separated, divorced, } \\
\text { or widowed }\end{array}$ & $21(16.5)$ & 78 (14.5) & $191(16.6)$ \\
\hline Missing & 0 & $4(0.8)$ & $11(1.0)$ \\
\hline \multicolumn{4}{|l|}{ Race } \\
\hline White & $116(91.8)$ & $483(90.1)$ & $1078(93.9)$ \\
\hline Non-white & $8(6.6)$ & $39(7.2)$ & $47(4.1)$ \\
\hline Not indicated & $2(1.6)$ & $14(2.7)$ & $23(2.0)$ \\
\hline Mean (SD) age in years & $42.7(11.1)$ & $41.1(10.8)$ & $44.6(11.7)$ \\
\hline Personal hourly income (median) & $\$ 21.54$ & $\$ 16.44$ & $\$ 17.91$ \\
\hline $\begin{array}{l}\text { Personal annual income (median) } \\
\text { Family income }\end{array}$ & $\$ 33337$ & $\$ 27660$ & $\$ 30241$ \\
\hline$<\$ 20000$ & $5(4.0)$ & $31(5.8)$ & 40 (3.5) \\
\hline$\$ 20000-39999$ & $24(19.0)$ & $116(21.7)$ & $231(20.1)$ \\
\hline \$40000-59999 & $31(24.6)$ & $142(26.5)$ & $285(24.8)$ \\
\hline$\$ 60000-79999$ & $29(23.0)$ & 102 (19.0) & 198 (17.3) \\
\hline$\$ 80000-99999$ & $18(14.3)$ & $49(9.2)$ & $156(13.5)$ \\
\hline$\$ 100000+$ & $14(11.1)$ & 73 (13.6) & $166(14.4)$ \\
\hline Missing & $5(4.0)$ & $23(4.3)$ & $72(6.3)$ \\
\hline
\end{tabular}

*Some totals equal 126 due to weighting methods.

†Percentages may not equal $100 \%$ due to rounding error.

that indicated none. To create a dichotomous measure of non-physical violence, the four types of non-physical violent behaviors were combined and those who experienced nonphysical violence (defined as responding "occasionally" or more often to any of the four non-physical violence questions) were compared to those who experienced none (those who responded to all four questions with "rarely" or "never"). The rationale was based on discussion with the organization's violence prevention committee, which included personnel from management, labor, employee health and safety, and the employee assistance program. The committee felt that "rare" non-physical violent events are difficult to predict and they were unable to justify allocating resources to such prevention. Odds ratios (OR) and 95\% confidence intervals (CI) were calculated for the association between the outcomes and each exposure using

\begin{tabular}{lll} 
Table 3 & Perpetrator & characteristics (\%) \\
\hline & $\begin{array}{l}\text { Physical } \\
\text { violence } \\
(\mathbf{n}=\mathbf{1 2 7})\end{array}$ & $\begin{array}{l}\text { Non-physical } \\
\text { violence } \\
\text { ( } \mathbf{n}=536)\end{array}$ \\
\hline $\begin{array}{lll}\text { Employees' relationship } \\
\text { to perpetrator* }\end{array}$ & \\
Patient/client & 77 & 25 \\
Other employee & 6 & 50 \\
$\begin{array}{l}\text { Physician } \\
\text { Supervisor }\end{array}$ & 4 & 20 \\
$\begin{array}{l}\text { Perpetrator impaired } \\
\text { by disease, medication, } \\
\text { drugs, or alcohol }\end{array}$ & 68 & 22 \\
\hline
\end{tabular}

*More than one response option allowed; other response options not included in table due to low frequency include "subordinate", "visitor", "non-co-worker", "other", "vendor/consultant", and "unsure". logistic regression. Separate analyses were performed for physical and non-physical violence. All analyses were weighted to adjust for the proportionate sampling by job family. The weights were calculated as the proportion of the group in the population divided by the proportion of the group in the sample-that is, respondents. Multiple logistic regression was used to produce odds ratios of work related violence by the independent variables after adjusting for potentially confounding variables. ${ }^{38}$

\section{RESULTS}

From a total of 4166 employees and former employees selected to participate, 1751 employees responded with the long survey (response rate $=42 \%$ ) and 380 responded with the short survey (total response rate of $51 \%$ ). Table 1 presents the demographic characteristics of the sampled participants $(n=4166)$, compared with respondents to the long survey $(n=1751)$. While all differences between groups were small, the most notable difference was with respect to race as nonwhites were less likely to respond than whites. Table 2 shows the demographic characteristics of respondents, comparing those who experienced physical violence, non-physical violence, and no violence. The following results are based on long form respondents only.

Table 3 shows the perpetrator characteristics of physical and non-physical violence. Patients were most commonly the perpetrators for physical violence (77\%), while other employees were most commonly the perpetrators for non-physical violence $(50 \%)$.

Physical violence was experienced by 127 respondents, accounting for an annual incident rate of 7.25 per 100 employees. However, when this rate was adjusted for number of months employed during the year and hours worked, or FTE, the rate increased to 9.1 per 100 full time employees. 
Table 4 Estimates of risk of physical violence by job family; values are OR $(95 \% \mathrm{Cl})$

\begin{tabular}{|c|c|c|c|c|c|}
\hline $\begin{array}{l}\text { Exposures: } \\
\text { job family }\end{array}$ & No & $\begin{array}{l}\text { Physical violence } \\
\text { (unadjusted) }\end{array}$ & $\begin{array}{l}\text { Physical violence } \\
\text { (adjusted) } †\end{array}$ & $\begin{array}{l}\text { Physical violence } \\
\text { (adjusted) } \ddagger\end{array}$ & $\begin{array}{l}\text { Physical violence } \\
\text { (adjusted)§ }\end{array}$ \\
\hline Medical specialists & 343 & 1 & 1 & 1 & 1 \\
\hline Clerical & 205 & $0.1(0.0$ to 0.4$)$ * & $0.1(0.0 \text { to } 0.5)^{*}$ & $0.1(0.0 \text { to } 0.4)^{*}$ & $0.1(0.0$ to 0.5$)$ * \\
\hline Patient care assistants & 94 & $2.4(1.1 \text { to } 5.2)^{*}$ & $2.5(1.1 \text { to } 6.1)^{*}$ & $3.0(1.2 \text { to } 7.1)^{*}$ & $2.8(1.2 \text { to } 6.5)^{*}$ \\
\hline Professionals** & 438 & $0.3(0.1 \text { to } 0.8)^{*}$ & $0.3(0.1$ to 1.2$)$ & $0.3(.01 \text { to } 0.9)^{*}$ & $0.3(0.1 \text { to } 0.9)^{*}$ \\
\hline Nurses & 231 & $3.8(2.0 \text { to } 7.3)^{*}$ & $1.7(0.8$ to 3.5$)$ & $2.2(1.1 \text { to } 4.5)^{*}$ & $4.3(2.2 \text { to } 8.5)^{*}$ \\
\hline $\begin{array}{l}\text { Medical care } \\
\text { providers†† }\end{array}$ & 304 & $1.5(0.6$ to 3.7$)$ & $1.0(0.4$ to 2.9$)$ & $1.3(0.5$ to 3.7$)$ & $1.6(0.6$ to 4.5$)$ \\
\hline Other not classified $\neq \ddagger$ & 136 & $1.4(0.6$ to 3.1$)$ & $1.7(0.6$ to 5.1$)$ & $1.3(0.5$ to 3.6$)$ & $2.0(0.9$ to 4.8$)$ \\
\hline \multicolumn{6}{|c|}{$\begin{array}{l}\text { *95\% Cl does not include } 1[\text { with exceptions]. } \\
\text { †Adjusted for department, business unit, and patient contact. } \\
\text { †Adjusted for department, business unit, and hours worked. } \\
\text { §Adjusted for age, gender, race, marital status, education, and income. } \\
\text { TIncludes employees such as physical therapists, respiratory therapists, and medical technologists. } \\
\text { **Includes employees such as human resources personnel and management. } \\
\text { † Includes employees such as physicians, residents and interns, and nurse practitioners. } \\
\text { † Includes employees such as cooks, drivers, laundry aides, and housekeeping aides. }\end{array}$} \\
\hline
\end{tabular}

The study was also designed so that the actual number of events per person could be recorded, since subjects could be exposed to more than one incident of physical violence in the 12 month period. However, more than $10 \%$ of those indicating physical violence recorded 10 or more events in the previous year with half recording "too many to count", making these estimates unreliable. If the actual number of events were used instead to estimate the incidence of violence per person-year, the rate per person-year would be considerably higher than the rate of 9.1. Non-physical violence was experienced by 536 of the respondents for an annual rate of 30.6 per 100 employees.

Tables 4 and 5 show the results of the logistic regression models for physical violence and non-physical violence by job family, both unadjusted and adjusted. For physical violence, results show that patient care assistants had increased odds, adjusting for patient contact, compared with medical specialists, who were used as the reference group throughout. Clerical workers had decreased odds of physical violence, both with unadjusted and adjusted analyses. None of the job families differed with respect to non-physical violence with the exception of the "other not classified" group when adjusted for demographic characteristics; the increased odds for nurses was suggestive. Additional analyses (not shown) identified departments with increased odds of physical violence with adjustment for job family and business unit: intensive care (OR 4.9, 95\% CI 2.6 to 9.2); mental health (OR 6.0, 95\% CI 2.9 to 12.3); and emergency (OR 4.3, 95\% CI 1.7 to 11.2). Departments with increased odds of non-physical violence with adjustment for job family and business unit were mental health (OR 1.9, 95\% CI 1.1 to 3.3) and emergency (OR 3.0, 95\% CI 1.5 to 5.9 ).
Tables 6 and 7 show that percentage of patient contact time increased odds of physical violence and non-physical violence, even when adjusted for job family and business unit. Further analyses on patient contact were done (not shown). For physical violence, when adjustments were made for job family, department, and business unit, the odds increased with both moderate patient contact (OR 7.2, 95\% CI 2.5 to 20.3) and high patient contact (OR 9.0, 95\% CI 3.3 to 24.9). For non-physical violence, when adjustments were made for job family, department, and business unit, the odds again increased with moderate (OR 1.5, 95\% CI 1.1 to 2.1 ) and high (OR 1.9, 95\% CI 1.4 to 2.5) patient contact.

Adjustments were also made for patient contact with the number of hours worked (not shown). Categories used were 40 or more hours per week, 20-39 hours per week, and less than 20 hours per week. For physical violence, the odds were raised for moderate (OR 7.4, 95\% CI 2.8 to 19.5) and high (OR 10.3, 95\% CI 4.0 to 26.1) patient contact. For nonphysical violence, the odds were raised for high (OR 1.4, 95\% CIl.1 to 1.8) patient contact. Hours worked, when adjusted for patient contact, also showed elevated odds for those working 20-39 hours (compared with 40 or more hours) per week for physical violence (OR 2.6, 95\% CI 1.7 to 4.1 ) and for non-physical violence (OR $1.4,95 \%$ CI 1.1 to 1.7 ).

The results of supervisor support on physical and nonphysical violence are shown in table 8 . When measuring supervisor support with two items, increased supervisor support decreased the odds for both forms of violence, even after adjusting for employment and demographic characteristics. However, due to the possibility of overlapping content between the one question on support referring to hostility from a supervisor and the subsequent measurement of

Table 5 Estimates of risk of non-physical violence by job family; values are OR (95\% Cl)

\begin{tabular}{|c|c|c|c|c|c|}
\hline Exposures: job family & No & $\begin{array}{l}\text { Non-physical } \\
\text { violence } \\
\text { (unadjusted) }\end{array}$ & $\begin{array}{l}\text { Non-physical } \\
\text { violence } \\
\text { (adjusted) } †\end{array}$ & $\begin{array}{l}\text { Non-physical } \\
\text { violence } \\
\text { (adjusted) } \ddagger\end{array}$ & $\begin{array}{l}\text { Non-physical } \\
\text { violence } \\
\text { (adjusted)§ }\end{array}$ \\
\hline Medical specialists & 343 & 1 & 1 & 1 & 1 \\
\hline Clerical & 205 & 1.1 (0.8 to 1.5$)$ & $1.1(0.8$ to 1.7$)$ & $1.2(0.8$ to 1.7$)$ & $1.3(0.9$ to 2.0$)$ \\
\hline Patient care assistants & 94 & $1.1(0.7$ to 1.8$)$ & $1.1(0.6$ to 1.8$)$ & $1.3(0.8$ to 2.1$)$ & $1.2(0.7$ to 1.9$)$ \\
\hline Professionals & 438 & $0.9(0.6$ to 1.4$)$ & $1.1(0.7$ to 1.8$)$ & $1.1(0.7$ to 1.7$)$ & $1.1(0.7$ to 1.7$)$ \\
\hline Nurses & 231 & $1.3(0.9$ to 1.8$)$ & 0.9 (0.6 to 1.3$)$ & $0.9(0.6$ to 1.4$)$ & $1.4(1.0 \text { to } 2.1)^{*}$ \\
\hline Medical care providers & 304 & $0.9(0.5$ to 1.5$)$ & $0.9(0.5$ to 1.6$)$ & $1.1(0.6$ to 1.9$)$ & $1.1(0.6$ to 2.0$)$ \\
\hline Other not classified & 136 & $1.4(1.0 \text { to } 2.1)^{*}$ & $1.3(0.8$ to 2.2$)$ & $1.2(0.7$ to 1.9$)$ & $2.3(1.4 \text { to } 3.6)^{*}$ \\
\hline \multicolumn{6}{|c|}{$\begin{array}{l}\text { *95\% Cl does not include } 1 \text { [with exceptions]. } \\
\text { †Adjusted for department, business unit, and patient contact. } \\
\text { †Adjusted for department, business unit, and hours worked. } \\
\text { §Adjusted for age, gender, race, marital status, education, and income. }\end{array}$} \\
\hline
\end{tabular}


Table 6 Estimates of risk of physical violence by patient contact; values are OR $(95 \% \mathrm{Cl})$

\begin{tabular}{llll}
\hline Exposures & $\begin{array}{l}\text { Physical violence } \\
\text { (unadjusted) }\end{array}$ & $\begin{array}{l}\text { Physical violence } \\
\text { (adjusted) } t\end{array}$ & Physical violence (adjusted) $\ddagger$ \\
\hline $\begin{array}{l}\text { Patient contact } \\
\text { Low }(0 \%-20 \%)\end{array}$ & 1 & 1 & 1 \\
Moderate (21\%-74\%) & $9.9(3.8 \text { to } 25.6)^{*}$ & $5.9(2.1 \text { to } 16.0)^{*}$ & $6.7(2.4 \text { to } 18.6)^{*}$ \\
High $(75 \%+)$ & $14.5(5.8 \text { to } 36.4)^{*}$ & $7.8(2.9 \text { to } 20.8)^{*}$ & $8.6(3.2 \text { to } 23.1)^{*}$ \\
\hline *95\% Cl does not include 1[with exceptions]. & & \\
†Adjusted for job family. \\
†Adjusted for job family and business unit.
\end{tabular}

non-physical violence, which could be due to a supervisor, the question was dropped in a second analysis. In this latter analysis, with only one item measuring supervisor support ("my supervisor was concerned about the welfare of those under him or her"), the results for the association between supervisor support and non-physical violence showed all odds ratios equal to approximately one.

Sensitivity analyses utilizing the methods of Rothman and Greenland were conducted on exposure misclassification for patient contact and physical violence. ${ }^{39}$ For moderate patient contact, as long as case sensitivity (that is, the probability that someone classified as exposed was truly exposed) was $90 \%$ or better, patient contact increased the odds of physical violence.

\section{DISCUSSION}

The important findings of this study are that workers with increased patient contact had increased odds of physical violence, and, to a lesser extent, non-physical violence. Job families with increased odds of physical violence included patient care assistants and nurses, consistent with other research..$^{5-7}$ However, adjusting for patient contact resulted in increased odds of physical violence for patient care assistants, but not nurses. Comparable to results reported by Gerberich et $a,^{12}$ working in intensive care, mental health, and emergency departments were important risk factors for physical violence even with adjustment for job family and business unit. Patient contact is, in itself, a risk factor for physical and non-physical violence. Increased patient contact resulted in increased odds of both physical and non-physical violence even with adjustment for employment characteristics, consistent with other research. ${ }^{11} 122331$

Job family did not increase the odds of experiencing nonphysical violence; this is in contrast to research describing differences among job classes. ${ }^{31}$ The odds of non-physical violence increased with increasing patient contact, although not as dramatically as with physical violence. This is not surprising, given that patients themselves are a lesser source of non-physical violence than other employees.

Non-physical violence was more prevalent than physical violence in this study, consistent with the literature. ${ }^{12}$ However, the findings suggested that non-physical violence may not escalate into physical violence, because the perpetrators and the risk factors vary. Consistent with study findings, the employer associated with the current study has since rewritten its violence prevention policies as three separate documents which address physical violence, sexual harassment, and the creation of a respectful workplace.

There is no mandate from the Occupational Safety and Health Administration (OSHA) or other authority regarding work related violence prevention measures-only recommendations. OSHA established guidelines to aid in the prevention of violence for health care workers. ${ }^{40}$ The National Institute for Occupational Safety and Health published a document addressing the increased risk of violence in hospitals $(8.3$ assaults per 10000 workers), compared with all private sector industries (2 per 10000 workers). ${ }^{41}$ However, little research has been conducted into risk factor identification for preventing such violence.

Support measures have rarely been addressed in violence studies; yet results from this study suggest that supervisor support in the work environment was protective for physical and non-physical violence. As operationalized in this study, supervisor support included both perceived concern about employee welfare and an absence of hostility or conflict in relationships. This finding is consistent with results indicating that support after an incident of violence can lead to a reduction in future violence. ${ }^{28} 29$ However, because supervisors were sometimes the perpetrators of violence, there may be content overlap between the predictor and the outcome of non-physical violence, contributing to an artificially high association between the two variables.

The potential limitations for this study include possible recall bias and selection bias. Subjects may be more likely to remember serious events or exclude less serious ones. However, information such as number of hours worked was obtained directly from the employee database making it more accurate than subject recall to assess for potential exposure. Limiting recall to the previous 12 months has been used successfully in other studies of work related assaults. ${ }^{12}{ }^{42}$ Potential selection bias is another limitation, in that survey respondents may have been more or less likely to experience violence than non-respondents. While confidentiality was assured, some subjects expressed concern regarding the manner in which results would be reported back to their employer. There may also be misclassification if subjects

Table 7 Estimates of risk of non-physical violence by patient contact; values are OR $195 \%$ Cl)

\begin{tabular}{llll}
\hline Exposures & $\begin{array}{l}\text { Non-physical } \\
\text { violence(unadjusted) }\end{array}$ & $\begin{array}{l}\text { Non-physical violence } \\
\text { (adjusted) } \dagger\end{array}$ & $\begin{array}{l}\text { Non-physical violence } \\
\text { (adjusted) } \ddagger\end{array}$ \\
\hline $\begin{array}{l}\text { Patient contact } \\
\text { Low }(0 \%-20 \%)\end{array}$ & 1 & 1 & 1 \\
Moderate $(21 \%-74 \%)$ & $1.3(1.0 \text { to } 1.7)^{*}$ & $1.4(1.1 \text { to } 2.0)^{*}$ & $1.5(1.1 \text { to } 2.0)^{*}$ \\
High $(75 \%+)$ & $1.5(1.2 \text { to } 2.0)^{*}$ & $1.7(1.3 \text { to } 2.3)^{*}$ & $1.8(1.3 \text { to } 2.4)^{*}$ \\
\hline
\end{tabular}

*95\% Cl does not include 1 [with exceptions].

†Adjusted for job family.

$\ddagger$ Adjusted for job family and business unit 
Table 8 Estimates of risk of physical and non-physical violence by supervisor support; values are OR $(95 \% \mathrm{Cl})$

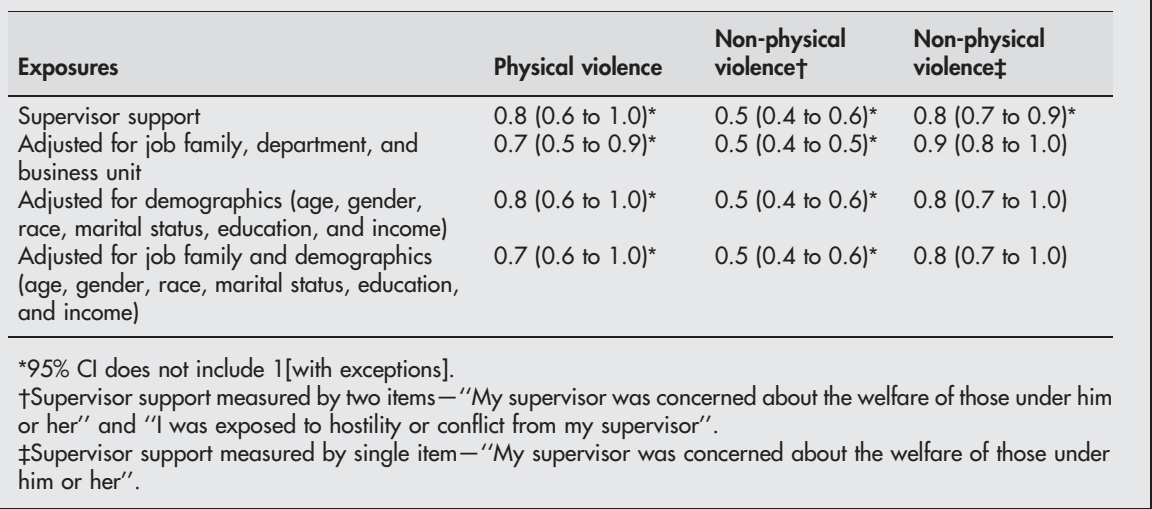

underreported their experience with violence because they felt it was an "expected" part of the job. The cross sectional nature of the study may have biased the population with workers with longer tenure. The extent to which length of employment greater than one year influences study participation, risk of assault, and the other factors of interest could bias the estimates. While all persons who ever worked for the employer were not enumerated, the inclusion of workers who left the organization within the 12 months before the study allowed some correction for the effect of employment duration. This study provides results from one individual Midwestern health care employer; therefore, results may not be generalizable to other health care institutions. The definition of violence used was that incorporated into the health care organization's violence policy and was intentionally broad. Worksite (cluster) information was not available due to confidentiality issues and, hence, analyses do not take into account possible non-independence of observations within worksite. This may lead to erroneously narrow 95\% confidence intervals.

Patient contact, defined here, included both face-to-face contact and telephone interaction. Future studies may want to separate these interactions. Patient interaction that involves close personal contact, such as performing personal care, may be separated from other, less direct, forms of patient contact to determine effects of violence.

\section{IMPLICATIONS FOR PREVENTION}

Much of the violence in health care workers research has emphasized physical violence. However, this study demonstrated that increased patient contact increases the risk of both physical and non-physical violence. Employees who encounter increased patient contact, including, but not limited to nurses, should be educated about the expected risk and follow up plans implemented to support employees and prevent future occurrences. This study demonstrated that supervisor support may be an important component in preventing future violence, but additional research affecting the mechanisms by which support prevents violence is needed. Likewise, additional job variables, such as patient characteristics and security measures, need to be researched further.

\section{ACKNOWLEDGEMENTS}

Support was provided, in part, by the Allina Health System Foundation; National Institute for Occupational Safety and Health's Midwest Center and its Pilot Project Research Training Program and the Occupational Health Nursing Program; American Association for Occupational Health Nursing Foundation; and National Occupational Research Agenda (NORA) Program (Midwest Center, University of Minnesota).

\section{Authors' affiliations}

M J Findorff, P M McGovern, S G Gerberich, B Alexander, Division of Environmental and Occupational Health, University of Minnesota, School of Public Health, Minneapolis, Minnesota

M Wall, Division of Biostatistics, University of Minnesota, School of Public Health, Minneapolis, Minnesota

\section{REFERENCES}

1 US Department of Labor, Bureau of Labor Statistics. National census of fatal occupational injuries in 2001. USDL 02-541 Washington, DC: US Department of Labor, 2002

2 Warchol G. National crime victimization survey: workplace violence, 19921996. Bureau of Justice Statistics Special Report Washington, DC: Bureau of Justice, 1998.

3 Toscano G. Workplace violence: an analysis of Bureau of Labor Statistics data. Occup Med: State of the Art Reviews 1996;11:227-36.

4 LaMar WJ, Gerberich SG, Lohman, et al. Work-related physical assault. J Occup Environ Med 1998;40:317-24.

5 Carmel H, Hunter M. Staff injuries from inpatient violence. Hospital and Community Psychiatry 1989;40:41-6.

6 Liss GM, McCaskell L. Injuries due to violence: workers' compensation claims among nurses in Ontario. AAOHN Journal 1994;42:384-90.

7 McGovern P, Kochevar L, Lohman W, et al. The cost of work-related physical assaults in Minnesota. Health Serv Res 2000;35:663-86.

8 Hashemi L, Webster BS. Non-fatal workplace violence workers' compensation claims (1993-1996). J Occup Environ Med 1998;40:561-7.

9 Pane GA, Winiarski AM, Salness KA. Aggression directed toward emergency department staff at a university teaching hospital. Ann Emerg Med 1991;20:283-6.

10 Peek-Asa C, Howard J, Vargas L, et al. Incidence of non-fatal workplace assault injuries determined from employer's reports in California. J Occup Environ Med 1997;39:44-50.

11 Williams MF. Violence and sexual harassment: impact on registered nurses in the workplace. AAOHN Journal 1996;44:73-7.

12 Gerberich SG, Church TR, McGovern PM, et al. An epidemiological study of the magnitude and consequences of work-related violence: The Minnesota Nurses Study. Occup Environ Med 2004; (in press).

13 Hurrell JJ, Worthington KA, Driscoll RJ. Job stress, gender, and workplace violence: analysis of assault experiences of state employees. In: VandenBos GR, Bulatao EQ, eds. Violence on the job: identifying risks and developing solutions. Washington, DC: American Psychological Association, 1996: 163-70.

14 Cameron L. Verbal abuse: a proactive approach. Nursing Management 1998;29:34-6

15 Cox HC. Verbal abuse in nursing: report of a study. Nursing Management 1987; 18:47-50.

$16 \mathrm{Cox} \mathrm{H}$. Verbal abuse nationwide, part II: impact and modifications. Nursing Management 1991;22:66-9.

17 Daugherty SR, Baldwin DC, Rowley BD. Learning, satisfaction, and mistreatment during medical internship: a national survey of working conditions. JAMA 1998;279:1194-9.

18 DeMayo RA. Patient sexual behaviors and sexual harassment: a national survey of physical therapists. Phys Ther 1997;77:739-44.

19 Finnis SJ, Robbins I, Bender MP. A pilot study of the prevalence and psychological sequelae of sexual harassment of nursing staff. Journal of Clinical Nursing 1993;2:23-7.

20 Finnis SJ, Robbins I. Sexual harassment of nurses: an occupational hazard? Journal of Clinical Nursing 1994;3:87-95

21 Frank E, Brogan D, Schiffman M. Prevalence and correlates of harassment among US women physicians. Arch Intern Med 1998;158:352-8.

22 Kaye J, Donald CG, Merker S. Sexual harassment of critical care nurses: a costly workplace issue. Am J Crit Care 1994;3:409-15.

23 Libbus MK, Bowman KG. Sexual harassment of female registered nurses in hospitals. Journal of Nursing Administration 1994;24:26-31. 
24 Vukovich MC. The prevalence of sexual harassment among female family practice residents in the United States. Violence Vict 1996; 1 1:175-80.

25 Simonowitz JA, Rigdon JE, Mannings J. Workplace violence: prevention efforts by the occupational health nurse. AAOHN Journal 1997;45:305-16.

26 US Department of Health and Human Services. Violence in the workplace: risk factors and prevention strategies. DHHS (NIOSH) Publication No 96-100. Washington, DC: US Department of Health and Human Services, 1996.

27 US Office of Personnel Management. Dealing with workplace violence: a guide for agency planners, 1998. Available at: http:// www.opm.gov/workplac.index.html-ssi.

28 Flannery RB, Penk WE, Hanson MA, et al. The assaulted staff action program guidelines for fielding a team. In: VandenBos GR, Bulatao EQ, eds. Violence on the job: identifying risks and developing solutions. Washington, DC: American Psychological Association, 1996:327-41.

29 Flannery RB, Hanson MA, Penk WE, et al. Replicated declines in assault rates after implementation of the assaulted staff action program. Psychiatr Serv 1998;49:241-3.

30 Sullivan C, Yuan C. Workplace assaults on minority health and mental health care workers in Los Angeles. Am J Public Health 1995;85:1011-14.

31 Braun K, Christle D, Walker D, et al. Verbal abuse of nurses and non-nurses. Nursing Management 1991;22:72-6.

32 Manderino MA, Berkey N. Verbal abuse of staff nurses by physicians. J Prof Nurs 1997;13:48-55.
33 Norris FH, Kaniasty KZ, Scheer DA. Use of mental health services among victims of crime: frequency, correlates, and subsequent recovery. J Consult Clin Psychol 1990;58:538-47.

34 Barling J. The prediction, experience, and consequences of workplace violence. In: VandenBox GR, Bulatao EQ, eds. Violence on the job: identifying risks and developing solutions. Washington, DC: American Psychological Association, 1996:29-49.

35 Flannery RB. Post-traumatic stress disorder. New York: Crossroad Publishing Company, 1992

36 Tomb DA. The phenomenology of post-traumatic stress disorder. Psychiatr Clin North Am 1994; 17:237-50.

37 Karasek R. Job content questionnaire. Los Angeles: Department of Industrial and Systems Engineering, University of Southern California, 1985.

38 Hosmer DW, Lemeshow S. Applied logistic regression. (Wiley series in probability and statistics: texts and references section.) New York: Wiley, 2000.

39 Rothman KJ, Greenland S. Modern epidemiology. Philadelphia, PA: Lippincott-Raven Publishers, 1998.

40 Occupational Safety and Health Administration (OSHA). US Department of Labor. Guidelines for preventing workplace violence for health care and social service workers, 1998. Available at: www.osha.gov/

41 National Institutes for Occupational Safety and Health. Violence: occupational hazards in hospitals. DHHS (NIOSH) Publication No 2002-101. Washington, DC: US Department of Health and Human Services, 2002. Available at: www.cdc.gov/niosh.

42 Lee SS, Gerberich SG, Waller LA, et al. Work-related assault injuries among nurses. Epidemiology 1999; 10:685-91. 